ORIGINAL ARTICLE, MEDICINE

\title{
Adaptation and Validation of a Burnout Inventory in a Survey of the Staff of a Correctional Institution in Bulgaria
}

\author{
Stanislava N. Harizanova ${ }^{1}$, Nonka G. Mateva², Tanya Ch. Tarnovska' \\ ${ }^{1}$ Department of Hygiene and Ecological Medicine, Faculty of Public Health, Medical University of Plovdiv, Plovdiv, Bulgaria \\ ${ }^{2}$ Department of Medical Informatics, Biostatistics and E-learning, Medical University of Plovdiv, Plovdiv, Bulgaria
}

\section{Correspondence:}

Stanislava N. Harizanova, Department of Hygiene and Ecological Medicine, Faculty of Public Health, Medical University of Plovdiv, Plovdiv, Bulgaria, 15A Vassil Aprilov Blvd., 4002 Plovdiv, Bulgaria

E-mail: dr.harizanovi@abv.bg Tel: +359887915119

Received: 04 Sept 2015

Accepted: 14 Feb 2016

Published Online: 12 Oct 2016

Published: 23 Dec 2016

Key words: burnout syndrome, questionnaires, prison staff, validity and reliability

Citation: Harizanova SN, Mateva NG, Tarnovska TC. Adaptation and validation of a burnout inventory in a survey of the staff of a correctional institution in Bulgaria.

Folia Medica 2016;58(4):282-288 doi: 10.1515/folmed-2016-0038
Background: Burnout syndrome is a phenomenon that seems to be studied globally in relation to all types of populations. The staff in the system of correctional institutions in Bulgaria, however, is oddly left out of this tendency. There is no standardized model in Bulgaria that can be used to detect possible susceptibility to professional burnout. The methods available at present only register the irreversible changes that have already set in the functioning of the individual. V. Boyko's method for burnout assessment allows clinicians to use individual approach to patients and affords easy comparability of results with data from other psychodiagnostic instruments. Adaptation of the assessment instruments to fit the specificities of a study population (linguistic, ethno-cultural, etc.) is obligatory so that the instrument could be correctly used and yield valid results. Validation is one of the most frequently used technique to achieve this.

Aim: The aim of the present study was to adapt and validate V. Boyko's burnout inventory for diagnosing burnout and assessment of the severity of the burnout syndrome in correctional officers.

Materials and methods: We conducted a pilot study with 50 officers working in the Plovdiv Regional Correction Facility by test-retest survey performed at an interval of 2 to 4 months. All participants completed the adapted questionnaire translated into Bulgarian voluntarily and anonymously. Statistical analysis was performed using SPSS v.17.

Results: We found a mild-to-strong statistically significant correlation $(P<0.01)$ across all subscales between the most frequently used questionnaire for assessing the burnout syndrome, the Maslach Burnout Inventory, and the tool we propose here. The high Cronbach's a coefficient $(a=0.94)$ and Spearman-Brown coefficient $\left(r_{s b}=0.86\right)$, and the low mean between-item correlation $(r=0.30)$ demonstrated the instrument's good reliability and validity.

Conclusion: With the validation herein presented we offer a highly reliable Bulgarian variant of Boyko's method for burnout assessment and research.

\section{BACKGROUND}

Research on different aspects of job stress is increasingly focusing on the comprehensive analysis and thorough explanation of burnout syndrome. This syndrome affects predominantly groups of professions such as social workers ${ }^{1-4}$, physicians $^{5-11}$, police officers $^{12-16}$, and teachers ${ }^{17-21}$.

The instrument most commonly used to assess this syndrome is the Maslach Burnout Syndrome Inventory $(\mathrm{MBI}) .^{22-25} \mathrm{MBI}$ was developed on the basis of a sample of 1025 subjects. It has three subscales to assess the different aspects of burnout: emotional exhaustion ( 9 items), depersonalization
(5 items) and personal accomplishment (8 items).

V. Boyko ${ }^{26}$, one of the most notable researchers of burnout syndrome in Russia, describes in detail the clinical picture of "emotional exhaustion" as a dynamic process. He introduced some extra features into the burnout syndrome definition: he distinguished three phases in the syndrome each manifestable with four symptoms with 7 items for each of them (Fig. 1).

V. Boyko developed an 84-item questionnaire to evaluate the phases and assess the degree of severity of the symptoms of burnout. ${ }^{27}$ Each item in its positive or negative variant carries a different 


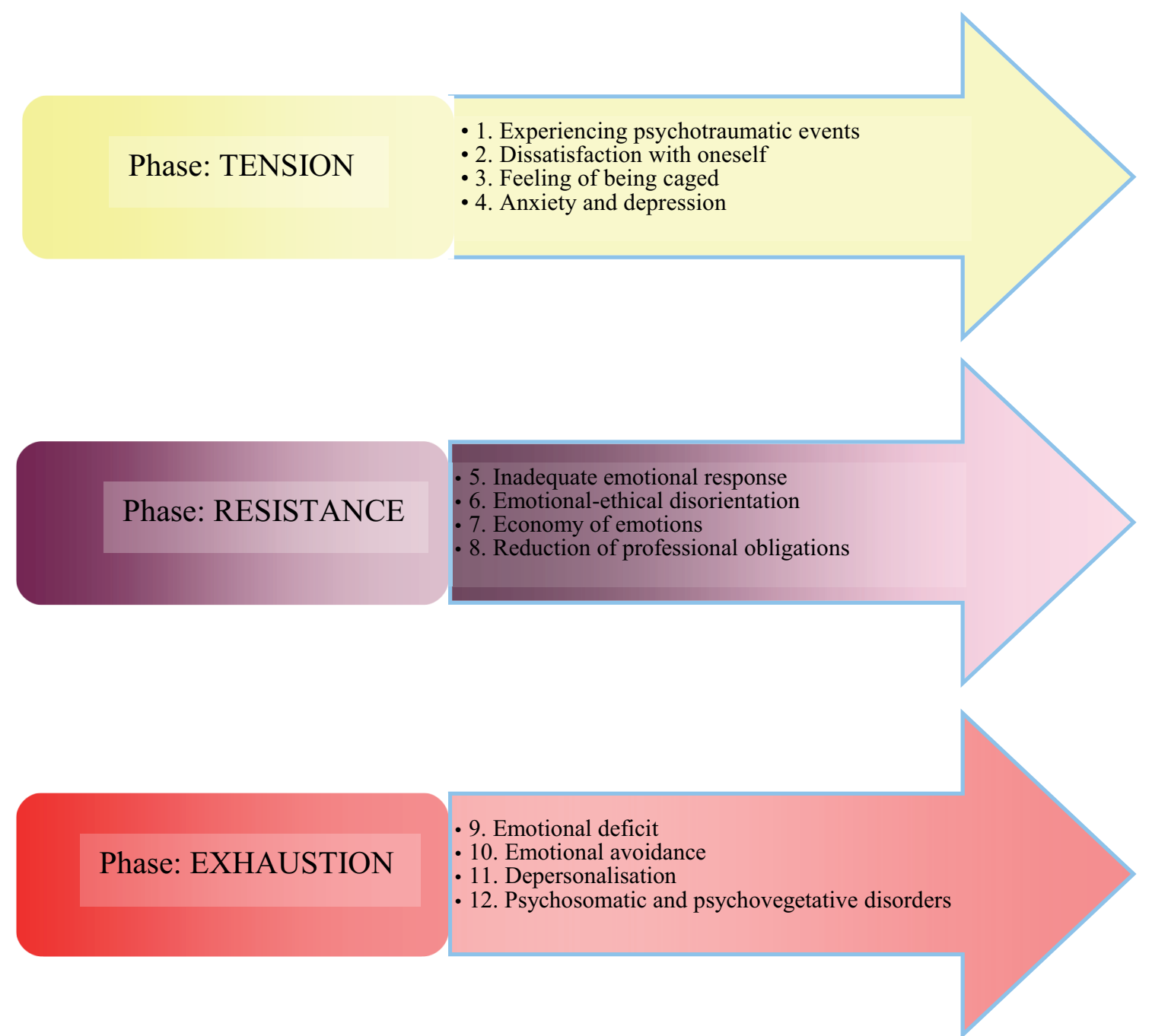

Figure 1. Symptoms and phases of burnout syndrome according to V. Boyko.

number of points $(1,2,3,5$ or 10 points), which allows the formation of a total score (range 0 to 30 points) for each of the symptoms. The higher the total score, the more pronounced is the symptom.

After the total score by symptoms is obtained the questionnaire starts forming a total score by phases. The rating by phases can be from 0 to 120 points. The quantitative indicators can indicate how complete a phase is, that is, what the level of development of the phase is. Table 1 shows the level of formation of symptoms and phases depending on the score obtained.

Special attention is devoted to symptoms scoring more that 20 points as they are the leading symp-

Table 1. Levels of formation of symptoms and stages of burnout syndrome depending on the total score

\begin{tabular}{lll}
\hline & Total score & \multicolumn{1}{c}{ Level of development } \\
\hline Symptoms & $<9$ & It is not important \\
& $10 \div 15$ & Beginning of formation \\
& $>16$ & The symptoms is active and there is a complication \\
& & \\
& $<36$ & The phase is not developed \\
Phases & $>61$ & In the process of development \\
& & The phase is developed \\
\end{tabular}


toms and the phase that contains them is defined as dominant. It is important to note to what phase of emergence of burnout syndrome are related the leading symptoms and in which phase they are the most numerous.

The clarity and uniformity of interpretation of the scales is an important advantage of Boyko's inventory. It makes it easier for clinicians to compare the obtained results with other psychodiagnostic techniques. A notable advantage of this instrument is the ability to use individual approach in the psychological prophylaxis and management of the burnout syndrome.

\section{AIM}

The aim of the present study was to adapt and validate V. Boyko's burnout inventory for diagnosing and assessment of the severity of the burnout syndrome in the personnel of some correctional institutions in Bulgaria.

\section{MATERIALS AND METHODS}

The study venue was the Plovdiv district prison facility. Primary data was collected through voluntary, anonymous survey of 50 male prison officers. The study was conducted at the workplace. The only criterion in the sample selection was the requirement for the officer to have direct contact with the inmates. Table 2 presents the individual characteristics of the study population.

The original version of the scale was translated from Russian into Bulgarian by a health care professional with excellent command of Russian so that we can analyse and define the items to precisely fit the criteria trends of the individual subscales. The resultant Bulgarian version of the original questionnaire was then back translated to Russian by a medical specialist who was a native Russian speaker and who had no access to the original Russian version. The resulting versions were given to another specialist who was an independent expert psychologist. He assessed each of the versions item by item and finding no substantial differences between the two variants endorsed the final version in Bulgarian. The results thus obtained entirely reproduced the original text. We also obtained permission by the author of the inventory V. Boyko to use his method in Bulgaria.

After having been instructed in great detail the participants in the survey completed the specially designed questionnaire twice at an interval of 2 to 4 months. This time interval between the two administrations was considered long enough for
Table 2. Characteristics of the study group

\begin{tabular}{|c|c|c|}
\hline Indicators & $\begin{array}{l}\text { Number } \\
\text { (n) }\end{array}$ & $\begin{array}{c}\text { Percentages } \\
(\%)\end{array}$ \\
\hline Age $(\mathrm{yrs})($ mean \pm SEM $)$ & $38 \pm 1$ & \\
\hline $\begin{array}{l}\text { Length of service }(y r s) \\
(\text { mean } \pm \text { SEM) }\end{array}$ & $10 \pm 1$ & \\
\hline \multicolumn{3}{|l|}{ Sex } \\
\hline Male & 50 & 100 \\
\hline \multicolumn{3}{|l|}{ Education } \\
\hline Secondary school & 12 & 24 \\
\hline $\begin{array}{l}\text { Secondary vocational } \\
\text { school }\end{array}$ & 25 & 50 \\
\hline Higher education & 13 & 26 \\
\hline \multicolumn{3}{|l|}{ Marital status } \\
\hline Married & 39 & 78 \\
\hline Single & 8 & 16 \\
\hline Divorced & 3 & 6 \\
\hline \multicolumn{3}{|l|}{ Rank } \\
\hline Police officer & 46 & 92 \\
\hline Chief police officer & 4 & 8 \\
\hline
\end{tabular}

the respondents to have forgotten their previous responses but short enough to assume that the underlying healthcare context had not changed thus producing substantial differences and making the results incomparable.

We also conducted external validation of the instrument by assessing the correlation with a different instrument for burnout assessment. We analyzed how well the results with the method we propose correlate with the results obtained by another well-known standardized inventory. The Maslach burnout inventory (MBI), officially validated for Bulgaria by B. Tzenova ${ }^{28}$, has been repeatedly administered in Bulgaria. The inventory uses three subscales according to the most common definition of burnout syndrome, namely, emotional exhaustion, depersonalization and reduced personal accomplishment. The validated Bulgarian version of the inventory uses the term dehumanization for "depersonalization" and "work efficiency" for the reduced personal accomplishments.

The primary data were analysed statistically using descriptive and analytical methods. The results are presented as mean \pm SEM. To assess the inventory 
reliability we used the split-half reliability model for each of the scales and calculated the SpearmanBrown coefficient $\left(\mathrm{r}_{\mathrm{sb}}\right)$. To assess the internal consistency and reliability of the scales we calculated the Cronbach's Alpha coefficient. We used also the means of the inter-item correlation coefficients. For external validation of the method we propose here we calculated the Pearson correlation coefficient using MBI. Statistical analysis was performed using SPSS v.17

\section{RESULTS AND DISCUSSION}

The scale's reliability was assessed with the Cronbach's alpha coefficient, the Spearman-Brown coefficient and the low mean inter-item correlation $(\mathrm{r}=0.30)$. The results of the test-retest survey are presented by the means and the mean errors (Table 3). The high values we obtained for the SpearmanBrown coefficient $\left(\mathrm{r}_{\mathrm{sb}}\right)$ confirmed the high degree of reliability of the instrument we propose.

There was no statistically significant difference between the obtained mean values of the subscales by symptoms in the two consecutive measurements, which is another proof that the scale has achieved a good reliability.

The internal consistency of each of the three phases and of the entire proposed instrument for assessment of burnout syndrome was verified by calculating the coefficient of internal consistency - the Cronbach's alpha coefficient (Table 4). The reliability of the method is good when the internal consistency of all scales is higher than $0.70 .^{29}$

In the present study, the values for the Cronbach's alpha coefficient vary in the range of 0.797 and 0.930 , with the internal consistency of the scale in general being very good $(\alpha=0.94)$. These values of Cronbach's $\alpha$ coefficients show that there is a high level of reliability of the used method.

The analysis of the internal consistency of the items across the entire scale shows that it possesses very good psychometric indicators and is well suited to be applied in the burnout assessment for correctional officers.

Table 5 presents the correlation analysis of the three subscales of Maslach burnout inventory along with the total score obtained with the proposed inventory. The MBI subscale for "emotional exhaustion" showed a strong direct positive correlation with the common scale in Boyko's inventory. The

Table 3. Estimation of the reliability of the Bulgarian translation for burnout syndrome assessment by the Spearman-Brown coefficient

\begin{tabular}{|c|c|c|c|c|}
\hline Symptoms & Number of items & $\begin{array}{l}\text { Means } \pm \text { SEM } \\
\text { I measurement }\end{array}$ & $\begin{array}{l}\text { Means } \pm \text { SEM } \\
\text { II measurement }\end{array}$ & rsb \\
\hline \multicolumn{5}{|l|}{ Phase: TENSION } \\
\hline Symptom 1. & 7 & $2.1 \pm 0.3$ & $2.5 \pm 0.6$ & 0.886 \\
\hline Symptom 2. & 7 & $2.1 \pm 0.3$ & $2.2 \pm 0.5$ & 0.873 \\
\hline Symptom 3. & 7 & $2.4 \pm 0.6$ & $2.4 \pm 0.4$ & 0.927 \\
\hline Symptom 4. & 7 & $2.8 \pm 0.5$ & $2.3 \pm 0.4$ & 0.913 \\
\hline \multicolumn{5}{|c|}{ Phase: RESISTANCE } \\
\hline Symptom 5. & 7 & $3.4 \pm 0.5$ & $2.1 \pm 0.4$ & 0.914 \\
\hline Symptom 6. & 7 & $2.2 \pm 0.3$ & $2.7 \pm 0.4$ & 0.909 \\
\hline Symptom 7. & 7 & $2.3 \pm 0.5$ & $2.1 \pm 0.5$ & 0.892 \\
\hline Symptom 8. & 7 & $3.2 \pm 0.3$ & $3.2 \pm 0.5$ & 0.722 \\
\hline \multicolumn{5}{|c|}{ Phase: EXHAUSTION } \\
\hline Symptom 9. & 7 & $1.6 \pm 0.2$ & $2.5 \pm 0.4$ & 0.682 \\
\hline Symptom 10. & 7 & $4.2 \pm 0.2$ & $2.9 \pm 0.4$ & 0.742 \\
\hline Symptom 11. & 7 & $2.0 \pm 0.5$ & $1.2 \pm 0.1$ & 0.912 \\
\hline Symptom 12. & 7 & $1.4 \pm 0.1$ & $1.8 \pm 0.2$ & 0.936 \\
\hline
\end{tabular}


Table 4. Estimation of reliability of the Bulgarian translation for burnout assessment through the Chronbach's alpha coefficient

\begin{tabular}{lcc}
\hline \multicolumn{1}{c}{ Scale } & $\mathbf{x} \pm \mathbf{S x}$ & $\begin{array}{c}\text { Chronbach's } \\
\text { alpha coeffi- } \\
\text { cient }\end{array}$ \\
\hline $\begin{array}{l}\text { Phase of overexten- } \\
\text { sion }\end{array}$ & $62 \pm 37$ & 0.930 \\
Phase of resistance & $93 \pm 39$ & 0.797 \\
$\begin{array}{l}\text { Phase of exhaustion } \\
\begin{array}{l}\text { Common assess- } \\
\text { ment scale }\end{array}\end{array}$ & $71 \pm 44$ & 0.876 \\
\hline
\end{tabular}

MBI subscale for "depersonalization" showed a moderate-to-strong correlation with the total score of the proposed instrument. A moderate negative correlation was found between the MBI subscale "personal accomplishment" and the studied scale.

The results suggest that there is moderate-tostrong correlation between the most commonly used questionnaire for assessment of burnout and Boyko's method we propose herein.

Boyko's inventory contains items related to various fields of human interaction in the profession

Table 5. Correlation between total score by B. Boyko's method and the MBI subscales

\begin{tabular}{lcc}
\hline \multicolumn{1}{c}{ MBI subscalese } & $\mathbf{r}$ & $\mathbf{P}$ \\
\hline Emotional exhaustion & 0.721 & 0.001 \\
Depersonalization & 0.511 & 0.001 \\
Work efficiency & -0.374 & 0.001 \\
\hline
\end{tabular}

and allows diagnosis of the extent of psychological protection and forms of burnout. Working with the meaningful content and with the quantitative indicators can give you enough information to be used in applying an individual approach in psychoprophylaxis and psychological correction. The respondents can be tested individually or in a group. Depending on the aim of the survey the questionnaires can be completed either anonymously or with identifiable details. The proposed assessment method should be administered, interpreted and analyzed by a specialist. All these makes the method very appropriate for assessment of the burnout syndrome.

\section{CONCLUSION}

The proposed Bulgarian variant of Boyko's burnout assessment inventory has high reliability and validity and can be administered successfully in surveying various professional groups including personnel working in correctional institutions.

\section{ACKNOWLEDGEMENTS}

The study is funded by the Research Fund at the Medical University, Plovdiv under Project No$22 / 2012$. The authors gratefully acknowledge the generous assistance of Inspector Psychologist Nina Galabova and the management of Plovdiv District Prison.

\section{REFERENCES}

1. Kim H, Ji JY, Kao D. Burnout and physical health among social workers: a three-year longitudinal study. Social Work 2011;56(3):258-68.

2. Kim H, Stoner M. Burnout and turnover intention among social workers: effects of role stress, job autonomy and social support. Administration in Social Work 2008;32(3):5-25.

3. Siebert DC. Personal and occupational factors in burnout among practicing social workers: implications for researchers, practitioners, and managers. J Soc Service Research 2005;32(2):25-44.

4. Lloyd C, King R, Chenoweth L. Social work, stress and burnout: A review. J Mental Health 2002;11(3):255-65.

5. Raycheva R, Asenova R, Kazakov DN, et al. The vulnerability to burn-out in health care personnel according to Stoyanov-Cloninger's model: evidence from a pilot study. Int J Pers Cent Medicine 2012;2(3):552-63.

6. Dimova R, Bakova D, Mateeva, et al. Testing medical staff in emergency sections, surgical departments and anesthesiology and intensive care units. In: Stoyanov D, editor. Personality, psychological climate and burnout syndrome. Sofia: East-West; 2012:158-75 (Bulgarian).

7. Assenova R, Foreva G, Dimotrova D. Testing general practitioners. In: Stoyanov D, editor. Personality, psychological climate and burnout syndrome. Sofia: East-West; 2012:190-9 (Bulgarian).

8. Nenova A, Rasheva A, Tsenova B, et al. Burnout and general characteristics of the job of medical staff in clinics of conventional treatment. Proceeding of $3 \mathrm{rd}$ National Psychology Congress. Sofia, Oct 28-30, 2005 (Bulgarian).

9. Maligin VL, Iskandirova AS, Pahtusova EE, et al. Social and psychological factors of the risk of inducing burnout syndrome in psychiatrists and 
drug addiction specialists. Medical Psychology in Russia: digitally published science journal. 2011;4 (Russian).

10. Pejuskovic B, Lecic-Tosevski D, Priebe S, et al. Burn-out syndrome among physicians - the role of personality dimensions and coping strategies. Psychiatria Danubina 2011;23(4):389-95.

11. Starr PN. Stress and burnout among cross-trained public safety personnel [dissertation]. Indiana University of Pennsylvania; 2009.

12. Ivie D, Garland B. Stress and burnout in policing: does military experience matter? Policing: I J Police Strategies \& Management 2011;34(1):49-66.

13. McCarty WP, Schuck A, Skogan W, et al. Stress, burnout, and health. National Institute of Justice, Topical Report 2011.

14. Beltrán CA, Moreno MP, Estrada JGS, et al. Social support, burnout syndrome and occupational exhaustion among mexican traffic police agents. Spanish J Psychol 2009;12(2):585-92.

15. Ranta RS, Sud A. Management of stress and burnout of police personnel. J Indian Academy Appl Psychol 2008;34(1):29-39.

16. Burke RJ, Mikkelson A. Burnout among Norwegian police officers: potential antecedents and consequences. I J Stress Management 2006;13:64-83.

17. Tsenova B. Occupational stress and mental health of teachers. Bulgarian Journal of Psychology 1996;4:46-72 (Bulgarian).

18. Chikova OM, Fominich EV. Diagnosing burnout syndrome in lecturers of mother institute that work in the affiliated institutions in the Northern cities. Siberian Journal of Psychology 2008;27:72-6 (Russian).

19. Brackett MA, Palomera R, Mojsa-Kaja J, et al. Emotion-regulation ability, burnout, and job satis- faction among British secondary-school teachers. Psychology in the School 2010;47(4):406-17.

20. Prieto LL, Soria MS, Martínez IM, et al. Extension of the Job Demands-Resources model in the prediction of burnout and engagement among teachers over time. Psicothema 2008;20(3):354-60.

21. Hakanen JJ, Bakker AB, Schaufeli WB. Burnout and work engagement among teachers. J School Psychology 2006;43:495-513.

22. Maslach C, Jackson SE. The measurement of experienced burnout. J of Occ Behav 1981a;2:99-113.

23. Maslach C, Jackson SE. MBI: Maslach Burnout Inventory. Manual Research Edition. Palo Alto, CA: Consulting Psychologists Press 1986.

24. Maslach C, Jackson SE, Leiter MP. Maslach Burnout Inventory. Manual, 3rd ed. Palo Alto, CA: Consulting Psychologists Press 1996.

25. Schaufeli WB, Enzmann D. The Burnout Companion to Study and Research: A Critical Analysis. London: Taylor \& Francis 1998.

26. Boyko V. A method of assessing the severity of burnout syndrome. In: Raigorodskii, editor. Practical Psychodiagnostics: Methodology of tests. Samara 1999; 161-9 (Russian).

27. Boyko V. Diagnosing burnout. In: Fetiskin NP, Kozlov VV, Manuylov GM, editors. Social and psychological diagnosis of the evolution of individuals and small groups of people. Moscow: Institute of Psychotherapy 2002:349-9 (Russian).

28. Tsenova B. Maslach Burnout Inventory. Authorized translation. National Centre of Hygiene and Medical Ecology, Sofia 1992 (Bulgarian).

29. Tabachnick BG, Fidell LS. Using multivariate statistics. 4th ed. New York: Harper and Row; 2001.

\title{
Адаптирование методики оценки синдрома эмоционального вы- горания при исследовании среди работающих в местах лишения свободы в Болгарии
}

\author{
Станислава Н. Харизанова ${ }^{1}$, Нонка Г. Матева², Таня Хр. Тарновска' \\ ${ }^{1}$ Кафедра гигиены и экологической медицины, Факультет общественного здоровья, Медицинский университет, Пловдив, \\ Болгария \\ ${ }^{2}$ Кафедра медицинской информатики, биостатистики и электронного обучения, Факультет общественного здоровья, \\ Медицинский университет, Пловдив, Болгария
}

Адрес для корреспонденции: Станислава Н. Харизанова, Кафедра гигиены и экологической медицины, Факультет Общественного здоровья, Медицинский университет - Пловдив, Болгария, бул. "Васил Априлов"
Контекст: Феномен эмоционального выгорания исследуется во всём мире. Независимо от этого, среди работающих в пенитенциарной системе в Болгарии синдром эмоционального выгорания не исследован. Отсутствует стандартизированная модель установления уязвимости к „профессиональному выгоранию". Существующие методы лишь регистрируют наступившие впоследствии изменения в функционировании индивида. 
15A, 4002 Пловдив, Болгариа E-mail:dr.harizanovi@abv.bg Тел.: +359 887915119

Дата получения: 04 сентября 2015 г.

Дата приемки: 14 февраля 2016 г.

Дата онлайн публикации: 12 октября 2016 г.

Дата публикации: 23 декабря 2016 r.

Ключевые слова: синдром эмоционального выгорания, анкеты, персонал в местах лишения свободы, валидация и надежность

Образец цитирования: Harizanova SN, Mateva NG, Tarnovska TC. Adaptation and validation of a burnout inventory in a survey of the staff of a correctional institution in Bulgaria.

Folia Medica 2016;58(4):282-288 doi: 10.1515/folmed-2016-0038
Методика Бойко для оценки синдрома эмоционального выгорания предоставляет возможность для индивидуального подхода и доступной сопоставляемости результатов с данными, полученными при применении других техник психодиагностики. Адаптирование инструментариума научных исследований к особенностям контингента (языковых, этнокультурных и др.) является обязательным условием для правильного проведения, исследования и выявления корректных результатов. Одним из наиболее широко использованных способов является валидизация.

Целью настоящего исследования является адаптирование и валидизация методики В. Бойко для диагностики и оценки тяжести синдрома эмоционального выгорания среди работающих в местах лишения свободы.

Материалы и методы: Провелось пилотное исследование среди 50 сотрудников Областной тюрьмы г. Пловдива при помощи тест-ретеста на протяжении срока от 2 до 4 месяцев. Все участвующие добровольно и анонимно заполнили адаптированный и переведённый на болгарский язык опросник. Статистическая обработка была осуществлена при помощи статистического софтуерного продукта SPSS v.17.

Результаты: Была установлена статистически значимая корреляционная связь средней до сильной силы $(P<0.01)$ по всем субшкалам между наиболее часто используемым опросником измерения синдрома эмоционального выгорания Maslach Burnout Inventory и предлагаемым нами исследовательским инструментом. Установленные высокие стоимости коэффициентов а Cronbach $(a=0.94)$ и Spearman-Brown $\left(r_{s b}=0.86\right)$, а также низкая средняя межпунктовая корреляция ( $r=0.30)$ являются показателями высокой надёжности и валидности.

Заключение: В результате осуществлённой валидизации мы предлагаем высоконадёжный болгарский вариант методики В. Бойко для исследования синдрома эмоционального выгорания. 